\title{
The Effect of the Mobile Learning Method on the Teaching of Milankovitch Cycles
}

Sibel Gürbüzoğlu Yalmancı

Kars Kafkas University, Faculty of Education, Turkey

\begin{abstract}
:
The aim of this study is to determine the effect of the subject of Milankovitch cycles which is addressed based on the mobile learning method on the success of students and the retentionof their knowledge. The model with the pretest-posttest control group which is included within the experimental design pattern was used in the study. The sampling of the research consists of 60 people studying at the Kars Science High School. In sample selection, whether the students possessed mobile phones, tablet computers connected to the internet, an e-mail address and basic skills in web-based applications was taken into consideration. Therefore, criterion sampling was utilized. Milankovitch Cycles Achievement Test (MCAT) developed by the researcher and was used as the data collection tool. According to research results, the subject of Milankovitch cycles has been understood better by the students through the activities which were prepared based on the mobile learning method and students' success has increased.
\end{abstract}

Keywords: Environmental education, extinction of living, Milankovitch cycles, mobile learning.

\section{Inönü University}

Journal of the Faculty of Education

Vol 18, No 1, 2017

pp. $15-26$

DOI: $10.17679 /$ inuefd.286126

\section{Suggested Citation}

Gürbüzoğlu Yalmancl, S. (2017). The Effect of the Mobile Learning Method on the Teaching of Milankovitch Cycles, Inonu University Journal of the Faculty of Education, 18(1), 15-26. DOI: 10.17679/inuefd.286126 


\section{INTRODUCTION}

Foundations of the climate system consist of the effect of cyclical dynamics such as the eccentricity of the earth's orbit, the concept of greenhouse effect and the potential of the release of the gases which retain heat to increase the atmosphere's temperature (Mc Caffrey \& Buhr, 2008). Climate system is affected under its own internal dynamics and by external factors and evolves. Among the external factors which cause climate change are the plate motions on the earth's crust (lithosphere), sun activities, the astronomical relations between the earth and the sun, man-made effects (greenhouse gases released to the atmosphere) and volcanic dust (Robock, 1978; Turkeş, 2013). In addition to the fact that astronomical relations which are named as "Milankovitch Cycles" contain a series of periodical changes, they are also important in terms of presenting proof to the explanation of long-term climate changes (Turkeş, 2013). Milankovitch has calculated the sun beams' solar irradiance values (insolation) which mean their density before passing to the atmosphere and has stated that glaciation has occurred in four main phases by establishing the radiation curve of the Pleistocene age (Schwarzacher, 1993). According to Milankovitch's theory, the astronomical relations between the earth and the sun are explained via three factors. These are axial tilt (Obliquity), orbital eccentricity (Eccentricity), orbital movement (Precession) (Berger and Loutre, 1994; Spiegel et al. 2010; Turkeş, 2013). According to obliquity, although the angle between the earth's axis and plane of the ecliptic is not fixed, it varies between 22.10 and 24.50 in 41.000- year periods. When the obliquity increases, summers in both hemispheres are warmer and sun beams are received less in winter. In eccentricity, the earth's orbit around the sun gradually turns into circular-shaped from ellipse and from circular-shaped to ellipse again in a 100.000 year time. When the earth's orbit is circular, the average energy amount the earth receives from the sun is low. Precession means the wobble of the earth's orbital axis. This wobble makes the earth closer and further from the sun. When the earth comes close to the sun in the long pole winter, the season of winter is warmer in the northern hemisphere (Schwarzacher, 1993; Turkeş, 2013; Tavşanoğlu, 2014).

Milankovitch cycles which are the causes of the climate change, i.e. the periodical changes in the earth's orbit, lead to major changes in the region and scale of the geographical distribution of species (Dynesius and Jansson, 2000). Although there has been a change among regions, such episodic fluctuations have occurred on a global scale (Bennet, 1997). Milankovitch theory explains the long-term climate changes which occurred during the Quaternary period (Berger and Loutre, 1994). This period is a time period in which dramatic climate changes were experienced (Bennet, 2004). The most significant event of this time is the emergence of human beings. In the Quaternary period which is divided into Pleistocene and Holocene epochs, the periodical repetition of glaciation, which affected the living vegetation greatly, has been observed. Glaciation occurred four times especially in Pleistocene and glaciers retreated in the inter-glacier period (Demirsoy, 2001; Akman, Duzenli and Guney, 2011). This glaciation has been effective in the northern hemisphere as well. The great ice masses which arose here made plant migration mandatory (Akman, Duzenli and Guney, 2011). As a reaction to the Quaternary climate change, latitude and altitude range of tree taxons changed (Davis and Shaw, 2001). As woody plants started to disappear, herbaceous plants took their places (Demirsoy, 2001). The climatic oscillations in this period have played a significant role in the geographical distribution of plant species (Comes and Kadereit, 1998). In Pleistocene, glaciers covered North America and Europe, majority of the species were not able to adapt to this situation, a part of them adapted and continued their existence while some migrated to the south (Demirsoy, 2001). Mammals such as Mastodon, giant deer, ground sloth, giant armadillo, cave bear have become extinct (Demirsoy, 2001). Many mammals such as mammoth, saber-tooth tiger started to become extinct with the emergence of humans in this period. Many straits were connected to each other with glaciers in this period as well and, hence, animals found the opportunity to spread (Demirsoy, 2001). From this perspective, the current genetic structure of the populations, species and communities have been shaped mostly by the Quaternary ice age (Hewitt, 2000). Milankovitch climate cycles are a primary factor which increases diversity in the long term (Jansson and Dynesius, 2002). The numbers of mammals, birds, reptiles, amphibians and vascular plant species in different geopolitical units on the earth's continents have decreased with the increase of the amplitude of Milankovitch climate cycles (Jansson and Dynesius, 2002). Familiarization with Milankovitch cycles in terms of the evolution, life and expansion area of the living beings is of utmost importance. Therefore, this cycle needs to have a significant place in science, biology and environment education.

When the latest curriculum in Turkey is examined, it is observed that the topic of global climate change is addressed within the "Current environmental problems and human beings" unit for the biology course (Ministry of National Education [MNE], 2013). Analyzing the content of the coursebook (MNE, 2014), it is found that this topic is referred to very briefly and especially global warming is mentioned, but long-term 
climate changes remain unaddressed. While in the 12th Grade, the title of "How the changes in nature affect evolution" has been given very briefly within the Origin of Life and Evolution unit (MNE, 2014) and global warming and human factor has been emphasized again. Examining the geography curriculum and coursebook (MNE, 2013; MNE, 2014), daily and yearly movements of the earth have been mentioned, the concept of climate and climate elements have been explained within the learning area, geological eras have been presented as a table and major events in these eras have been mentioned briefly on the side in the ninth grade coursebook. It has been observed that coursebooks do not mention the geological eras, longterm climate changes and, hence, factors which have an impact on climate change affecting the evolution and life of many species, including Milankovitch cycles which have an important place in the understanding of the last ice age, informatively and in detail. Due to these shortcomings in the coursebooks and curriculum, teachers will not be able to give this information to their students clearly. According to McCaffery and Buhr (2008), very few science teachers have the tools or education which are necessary to communicate the foundations of climate or complexity of climate change to students who are the future citizens and decisionmakers of the society. Hence, these shortcomings in coursebooks and teachers will lead to the development and comprehension of certain misconceptions in students. McCaffery and Buhr (2008) have stated that students have difficulty in understanding obliquity and, in addition, they have misconceptions about the earth's orbit around the sun, the sun's distance from the earth and its relative magnitude, and the span of earth's precession around the sun and its rotation period. Gowda, Fox and Magelky (1997) have stated that majority of students are not able to realize long-term climate change in distinguishing between weather and climate. These misconceptions and misbelieves are observed to be associated with Milankovitch cycles. Therefore, these cycles need to be taught through techniques and methods which can arouse the curiosity of students and provide their remembrance easily to eliminate knowledge deficiency and misconception among students about climate change. Students who have mlearned about Milankovitch cycles will understand climate change and, hence, how the living in the past were affected by it, the spread and evolution of the living beings, global warming and its results better. Thus, they can gain insight about the fate of the living beings in the near future and can question measures and actions to be taken accordingly. Therefore, mobile teaching model which is one of the methods that ensures the students' learning of Milankovitch cycles at the highest level and allows for the utilization of technology has been used in this study. Within the context of the relations between technology and education, new technologies can be stated to offer an effective learning environment, to reach more students and to have the capacity to change the structure of higher education (Atıcl, 2007). From this perspective, it is thought that students will gain active insight about the subject through the mobile teaching method.

According to Stone (2004) it is an e-learning can be done with networking technologies related to mobile learning device features. This method allows for distance learning and to move to another place by communicating through information networks. It provides entry to information networks to learners by using portable learning device and wireless network. It creates flexible learning environment at campus, at home, outside university facilities by ensuring flexible learning (Seppala \& Alamaki, 2003). Various learning materials and teacher-student interaction can be achieved in this learning all the time. Thus it established a link between classroom and outdoor learning (Georgieva, Smrikarov \& Georgiev, 2005).

By means of mobile education, life-long learning, unconscious learning, time and place independent learning, place and conditions adjustable learning can be provided. Mobile phones, handheld computers, tablet PCs and notebooks are the mobile tools generally used in education. The usage of these tools in education is divided into two as online and offline. Information can be obtained offline directly via the device, there is no connection fee or coverage area problem. Online education has advantages such as currency and access to infinite information (Bulun, Gulnar \& Guran, 2004). As Oran and Karadeniz (2007) have stated, database server, web server, wap server, SMS server, E-mail server, mobile phones, handheld computers, tablet computers, laptop computers are also included in internet-based mobile learning tools. Internet compatible mobile phones, tablets, SMS server, tape recorder have been utilized in this study.

Surveying the studies in the literature, it has been observed that they have given information about Milankovitch cycles and evolutionary results have been emphasized by giving information about the effect these cycles have on species (Bennet, 1990; Dynesius and Jansson, 2000; Jansson and Dynesius, 2002; Spiegel et al. 2010). In addition, informative studies on long-term climate changes and the Quaternary period which Milankovitch cycles explain have been encountered (Comes and Kadereit, 1998; Hewitt, 2000; Davis and Shaw, 2001; Bennett, 2004; Turkeş, 2013). While the studies about education have been generally aimed towards identifying the perceptions and misconceptions students have about climate change (Gowda, et. al, 
1997; Fortner, 2001; Shepardson et al. 2009; Lombardi \& Sinatra, 2012). No study has been found in the literature about the usage of Milankovitch cycles in education. As this study will be a first in the implementation Milankovitch cycles to education, it is believed that it will contribute to the field.

The survey conducted for Mobile learning is often mentioned that mobile learning based courses increase the academic success of students and develop a positive attitude towards these methods (Al-Fahad, 2009; Chen, 2013; Ciampa, 2014; Jaradat, 2014; Kutluk ve Gulmez, 2014).

Biology, evolution and environmental fields, which is of great importance of this issue, for better understanding, enabling students both individual and collaborative learning both at school gives you the opportunity to work outside of school, it was decided that the use of mobilelearning. It is believed that this work will contribute to the field of teaching Milankovitch's cycles because Milankovitch cycles that explain how life begins and ends and how it is done and gives information for future life will be better understood by mobile learning methods that actively engage students and that what matters for life is important.

Accordingly, the aim of this study is to determine the effect of the subject of Milankovitch cycles which is addressed based on the mobile learning method on the success of students and the retentionof their knowledge. In this regard, it is to answer the following sub-problems.

i. Is there a meaningful difference between pretest-posttest points of experiment group to whom the subject of Milankovitch cycles was taught according to mobil learning and control group to whom the same subject was discussed according to MEB-approved guide book?

ii. Is there a meaningful difference between pretest-posttest points and permanence test points of experiment group to whom the subject of Milankovitch cycles was taught according to mobil learning and control group to whom the same subject was discussed according to MEB-approved guide book?

\section{Model}

\section{METHOD}

In this study, Milankovitch cycles were addressed based on the mobile learning method in the experiment group and by adhering to the teaching method suggested by the MEB-approved guide book in the control group and the effect of these methods on the success of students and retentionof their knowledge was attempted to be determined. To this end, the model with the pretest-posttest control group which is included within the experimental design pattern and is based the formation of two groups through neutral designation was used in the study (Karasar,2008). This method is appropriate for determining the cause and effect relationship between variables.

Table 1. Schematic representation of the pattern

\begin{tabular}{lllll}
\hline Working Group & Before Application & $\begin{array}{l}\text { Application } \\
\text { Process }\end{array}$ & Post Application & $\begin{array}{l}\text { After the Post } \\
\text { test }\end{array}$ \\
\hline Control & Pretest & 5E Model & Posttest & Retention test \\
\hline Experiment & Pretest & Mobile learning & Posttest & Retention test \\
\hline
\end{tabular}

\section{Population and Sampling}

The population of the research consists of the students in the high schools of the Kars Province who have the criteria in sampling selection. The sampling of the research consists of 60 people studying at the Kars Science High School. In sample selection, whether the students possessed mobile phones, tablet computers connected to the internet, an e-mail address and basic skills in web-based applications (ability to send emails, to draw) was taken into consideration. Therefore, criterion sampling was utilized. This sampling can be used in the implementation on people possessing certain characteristics (Buyukozturk et al. 2011). To achieve neutrality, extra attention was paid to the existence of these characteristics in both groups. Information received from teachers about the level of student and teachers stated that the level of students in both groups they are similar. Implementations were carried by the students' own biology teachers in both groups to ensure impartiality. In addition, success pre-test scores of the groups were also examined and no significant difference was observed. Both groups selected in this manner consist of 30 people each. In the 
experiment group, there are 18 female and 12 male students and in the control group, there are 16 female 14 male students.

\section{Measurement Tool and Data Analysis}

\section{Milankovitch cycles achievement test}

Milankovitch Cycles Achievement Test (MCAT) developed by the researcher which targets the effect of climate change and Milankovitch cycles on the life of living beings was used as the data collection tool. In the preparation of the questions in the achievement test, 15 questions were prepared on the level of information, analysis and evaluation about Milankovitch cycles by taking the attainments of "student questions the causes and possible results of current environment problems" in the MEB-approved ninthgrade biology curriculum and "student analyzes the change and causes of the living diversity throughout the history of the living" in the 12th grade biology curriculum into consideration. The questions in this test were shown to three experts to ensure content validity. The questions were rearranged in line with the feedback obtained from the experts. A pilot application was conducted on a group of 70 to conduct the validity and reliability analyses of the test. With the prediction that high schools students were never taught the subjects of climate change and Milankovitch cycles as stated in the introduction part of this study, it was believed that these students would have difficulty in the test they would be given and, hence, the pilot application was implemented on the students at the Department of Social Sciences of Kafkas University. These students compared to other branches has received more geography lesson and was confronted with information about the Milankovitch cycles. As a result of the pilot application, item difficulty and distinctiveness indices of the items were calculated. Firstly, answer sheets were organized from the highest score to the lowest. The number of students included in the bracket $27 \%$ was determined to identify upper and lower groups $(70 \times 27 / 100 \approx 20)$. The item difficulty index was calculated with the $P=(D U+D A) / N U+N A$ formula and item distinctiveness was calculated with the $D=(D U-D A) / N U$ or NA formula (NU= Number of students in the upper group, $N A=$ Number of students in the lower group, $D U=$ Number of students who answered the item correctly in the upper group, DA= Number of students who answered the item correctly in the lower group). Accordingly, the second and seventh question whose item difficulty index is close to zero and item distinctiveness is less than .20 were left out of the test. The mean difficulty and mean distinctiveness of the test were calculated as .46 and .66 respectively. According to Cepni et al. (2008), the mean difficulty of the test is preferred to be around 0.5 . The Cronbach Alpha reliability coefficient of the test was calculated as .80 . In this case, the test can be said to be reliable. 8 of the question included in the test are at the knowledge level, 2 of them are at the analysis level and 3 of them are at the evaluation level. These questions were prepared in a manner to help students analyze the causes and consequences of environmental problems and the change and causes of the diversity of living beings. The questions involve the causes of climate change, addressing of these causes in the light of the Milankovitch cycle and the questioning of the results of this cycle and its importance for living beings.

Table 2

Item difficulty and item distinctiveness values of the test items

\begin{tabular}{|c|c|c|c|c|c|c|c|c|c|c|c|c|c|c|c|}
\hline Items & 1 & 2 & 3 & 4 & 5 & 6 & 7 & 8 & 9 & 10 & 11 & 12 & 13 & 14 & 15 \\
\hline $\begin{array}{l}\text { Item Difficulty } \\
\text { Value }\end{array}$ & .62 & .22 & .5 & .37 & .5 & .4 & .25 & .47 & .5 & .37 & .45 & .45 & .52 & .37 & .5 \\
\hline $\begin{array}{l}\text { Item } \\
\text { Distinctiveness } \\
\text { Value }\end{array}$ & .35 & .15 & .7 & .75 & .7 & .7 & .05 & .95 & .6 & .35 & .7 & .8 & .55 & .75 & .7 \\
\hline $\begin{array}{l}\text { Item Difficulty } \\
\text { Mean Value }\end{array}$ & .46 & & & & & & & & & & & & & & \\
\hline $\begin{array}{l}\text { Item } \\
\text { Distinctiveness } \\
\text { Mean Value }\end{array}$ & .66 & & & & & & & & & & & & & & \\
\hline
\end{tabular}




\section{Implementation}

Implementation was conducted in the second semester of the 2014-2015 academic year. Of the two groups consisting of thirty people each, Milankovitch cycles were explained to the control group through the method recommended by the MEB-approved guide book ( $5 \mathrm{E}$ model) in line with the identified aims and attainments (Enter stage: The course starts with an intriguing way. "How has the fate of the living beings changed?" questions are asked to students and received their ideas. Explore stage: The video transmits to students about Milankovitch cycles and discuss among themselves to solve the original problem. Explain stage: Scientific explanations about the Milankovitch cycles is done by the teacher. Elaborate stage: The relationship between the Milankovitch cycles and the extinction of living will be asked to students. They investigate the this issue and use the term and information they receive. Evaluate stage: Theacher monitors students to solve problems and evaluate their progress. Students can also evaluate themselves.) while in the experiment group, applications based on the mobile learning method were carried out. Implementations were carried by the students' own biology teachers in both groups to ensure impartiality. In the experiment group, Milankovitch cycles were addressed through the question-answer and discussion method which is one of the student-centered teaching models allowing for active student participation and comments within the classroom and a smart board, a technological tool which has an important place in education, was used in the teaching of the class. In this group, the teacher taped the teaching of the class and sent it to the emails of the students. Outside the classroom, the part of a National Geographic (http://channel.nationalgeographic.com) documentary which is about the Milankovitch cycle was uploaded to the students' tablets, students were asked to share the information they obtained from the documentary with their friends via e-mail, concepts maps about climate change and Milankovitch cycles were sent to the students' e-mails and students were asked to send their own concepts maps about this subject to their teacher's e-mail. In addition, short reminders and questions about the subject were sent to the students' mobile phones every other day and students sent the answers to the questions via SMS. The video, documentary, questions and reminders used in the implementation were prepared upon consultation with experts. These activities lasted three weeks and a total of 12 hours. In 1 week of the three weeks, i.e. 4 hours, in-class applications were carried out. The remaining 2 weeks, i.e. 8 hours, occurred outside the classroom. Before these applications, both groups were implemented the achievement test in its latest form to determined the similarity level of the groups. The achievement test was reimplemented after the applications and the students' success were examined after applications and explanation. Four weeks later upon the implementation of this test, achievement test was re-implemented to determine the retention of the students knowledge.

\section{FINDINGS}

Mobile learning started with applications such as mobile exam and mobile course and continued with audiovisual applications with the development of $3 G$ and $4 G$ technologies. Access to information is more rapidly available thanks to mobile devices (Işık, Ozkaraca and Guler, 2011). In this section of the study which examines the success of the students, the arithmetic mean, standard deviation and average attainment level of the pretest and posttest scores obtained from the MCATs of the students in the control and experiment groups have been presented in Table 2.

Table 3

Arithmetic Mean, Standard Deviation And Average Attainment And T-Test Values Of The Pretest And Posttest Scores Obtained From MCAT

\begin{tabular}{|c|c|c|c|c|c|c|c|c|c|c|c|c|}
\hline Groups & $\mathrm{N}$ & $\begin{array}{l}\text { Pre- } \\
\text { test } \\
\bar{X} \\
\end{array}$ & SD & $d f$ & $\mathrm{t}$ & $\mathrm{p}$ & $\begin{array}{l}\text { Post- } \\
\text { test } \\
\bar{X}\end{array}$ & SD & $d f$ & $\mathrm{t}$ & $p$ & $\begin{array}{l}\text { Average } \\
\text { Attainment }\end{array}$ \\
\hline Experiment & 30 & 5.53 & 1.88 & 58 & -.63 & .52 & 11.86 & 1.45 & 58 & 6.97 & .00 & 6.33 \\
\hline Control & 30 & 5.83 & 1.76 & & & & 8.80 & 1.91 & & & & 2.97 \\
\hline
\end{tabular}

According to Table 3, an increase is observed in the scores students in the experiment and control groups obtained from the achievement test before and after the implementation. However, it is observed that the average attainment values of the students in the experiment group are higher than that of the ones in the control group. According to the t-test results conducted on the pre-test scores of the students in the experiment and control groups, no meaningful difference has been found between the groups $(t(58)=-.63$, $p>.05)$. In this case, it can be stated that the students in the groups are at the same level in terms of the 
achievement test. In terms of the posttest, whether there is a difference between the groups or not have been examined through t-test $(t(62)=7.97, p<.05)$. A significant difference has been found in favour of the experiment group students. In this case, it can be stated that mobile learning is effective in the teaching of Milankovitch Cycles. When the findings on the effect of the Milankovitch cycles, which is addressed based on the mobile learning method, on the retentionof the students' knowledge are examined, ANOVA test on the scores students in the experiment and control groups obtained from the MCAT conducted 4 weeks after the applications have been presented in Table 4

Table 3

Values of the ANOVA test on the scores students in the experiment and control groups obtained from the pre, post and retention achievement test.

\begin{tabular}{|c|c|c|c|c|c|c|c|}
\hline Groups & Variance source & $\begin{array}{l}\text { Sum } \\
\text { squares }\end{array}$ & of $\mathrm{df}$ & $\begin{array}{l}\text { Sum of } \\
\text { Squares }\end{array}$ & $\mathrm{F}$ & $p$ & $\begin{array}{l}\text { Significant } \\
\text { difference }\end{array}$ \\
\hline \multirow[t]{4}{*}{ Experiment } & Among subjects & 106.72 & 29 & 3.68 & 22.97 & $.00^{*}$ & $1-2$ \\
\hline & Measurement & 54.15 & 1 & 54.15 & & & $2-3$ \\
\hline & Error & 68.35 & 29 & 2.35 & & & $1-3$ \\
\hline & Total & 229.22 & 59 & & & & \\
\hline \multirow[t]{4}{*}{ Control } & Among subjects & 82.26 & 29 & 2.83 & 51.54 & $.00 *$ & $1-2$ \\
\hline & Measurement & 1.06 & 1 & 1.06 & & & $2-3$ \\
\hline & Error & 87.93 & 29 & 3.03 & & & \\
\hline & Total & 171.25 & 59 & & & & \\
\hline
\end{tabular}

1: Pretest 2: Posttest 3: Retention test ${ }^{*} \mathrm{p}<.05$

When Table 4 is examined, a significant difference is found in the scores experiment group students obtained from the pre, post and retentiontest $[F(1.29)=22.97 p<0.05]$. It has been observed that this difference exists between the pretest and posttest, posttest and retention, pretest and retention test through the conducted Bonferroni test. A significant difference has also been found between the tests implemented on the control group students $[F(1.29)=51.54 p<0.05]$ and this difference has been observed to be between the pretest and posttest, and posttest and retention test. The average scores and standard deviation values of both groups related to these test have been presented in Table 5 .

\begin{tabular}{lllll}
\hline Groups & Tests & $\mathrm{N}$ & $\bar{X}$ & SS \\
\hline Experiment & Pretest & 30 & 5.53 & 1.88 \\
& Posttest & 30 & 11.86 & 1.45 \\
& Retention & 30 & 7.43 & 1.88 \\
\hline Control & Pretest & 30 & 5.83 & 1.76 \\
& Posttest & 30 & 8.80 & 1.91 \\
& Retention & 30 & 5.56 & 1.67 \\
\hline
\end{tabular}

As can be seen in Table 5, scores of both groups in the retentiontest have shown a decrease compared to their scores in the posttest. However, the retentionscores of the students in the experiment groups are higher than their pretest scores by contrast with the students in the control group. Therefore, it can be stated that the applications in the mobile learning method increase student success and are more effective in the retentionof the knowledge according to the teaching method recommended by the MEB-approved guidebook.

\section{CONCLUSION, DISCUSSION AND SUGGESTIONS}

According to research results, the subject of Milankovitch cycles has been understood better by the students through the activities which were prepared based on the mobile learning method and students success has increased. Numerous studies which support this conclusion have been found AtıCl, 2007; Wang et al. 2009; Hwang and Chang, 2011). This method has been more effective in the retentionof students' knowledge. The conclusion that mobile learning methods increase the retentionin the knowledge of students has also been reached by Eryllmaz (2013). This method which has such a positive effect on learning can be used as a learning tool students may prefer in other courses as well. In this study which aimed to determine the attitude 
and views of students on mobile learning, Al-Fahad (2009) has stated that most of the students have adopted the idea of mobile learning and see this method as a way to study on their own. Waycott and KukulskaHulme (2003) have investigated whether mobile devices affect the reading strategies of students and have concluded that students prefer mobile devices to coursebooks. Thus, students wish to prefer technological tools and materials for learning in line with what this age requires. This wish needs to be set to work without being overlooked in education and teaching programmes. It is of utmost importance that students have the necessary basic information about these technological devices at this point. Therefore, students need to be introduced to technology in the preschool education as well. As can be seen in this study, the mobile learning method in the teaching of Milankovitch cycles, which are not included in high school curriculum and students have encountered for the first time, has been vert effective in both their success and the retentionof their knowledge. Thus, the effectiveness of this method in the teaching of abstract subjects is clear. The factor which affects this may arise from the fact that this method is not limited to only one device such as a computer. The student has the opportunity to use almost all types of technological tool in education and can more easily proceed at his/her own learning pace. Educators have also focused on the authentic learning activity which allows students to work on a problem in the real world (Brown, Collins and Duguid, 1989). The design of courses which merge the real world and the digital world through the use of mobile and wireless communication technologies has gained importance (Chu, Hwang, Tsai and Tseng 2010). The method which has achieved this is the mobile learning method. Although student-centered method $5 \mathrm{E}$ and mobile learning use of from both groups, mobile learning has been shown to be more effective. It can be say that the mobile learning method is more efficient in learning due to give the students opportunity yo work their own pace and presented more experience and strengthening to students.

According to the results of this study contribute to the field of research can be summarized as follows:

1. including abstract information which this issue has been learned more easily so it can be used in other subjects including abstract information in the field.

2. increased student achievement and retention of information in the mind. It can be used in other subjects including misconceptions and elusive information in the field.

The mobile learning method which ensures time and space independent education has been begun to be implemented all over the world by people who are aware of its importance. It is suggested that this method which has positive effects on the learning of students be widely used in other disciplines and classes be equipped with mobile tools and materials. In addition, qualitative studies in which student opinions are received can be conducted in the future. Except that in learning abstract issues and topics that are misunderstanding the use of mobile learning methods have been proposed.

\section{REFERENCES}

Akman, Y., Duzenli A., and Guney K. (2011). Biyocoğrafya (Biogeography). Ankara: Palme Yayıncılık.

All-Fahad, F.N. (2009). Students' attitudes and perceptions towards the effectiveness of obile learning in King Saud University, Saudi Arabia. The Turkish Online Journal the of Educational Technology, 8(2), 111119.

Atıcı, B. (2007). The efficiency of virtual learning environments based on social knowledge construction on learners' achievement and attitudes. Education and Science, 32 (143), 41-54.

Bennett, K.D. (1990). Milankovitch cycles and their effects on species in ecological and evolutionary time. Paleobiology, 11-21.

Bennett, K.D. (1997). Evolution and Ecology: The Pace of Life. Cambridge: Cambridge Univ. Press.

Bennett, K.D. (2004). Continuing the debate on the role of Quaternary environmental change for macroevolution. Royal Society, 359, 295-303. DOI 10.1098/rstb.2003.1395

Berger, A., and Loutre, M.F. (1994). Precession, eccentricity, obliquity, insolation and paleoclimates. In LongTerm Climatic Variations (pp. 107-151). Springer Berlin Heidelberg.

Brown, J.S., Collins A., and Duguid, P. (1989). Situated cognition and the culture of learning. Educational Researcher, 18(1), 32-42.

Bulun, M., Gulnar, B., and Guran, M.S. (2004). Eğitimde mobil teknolojiler (Mobile Techonologies in Education). The Turkish Online Journal of Educational Technology, 3(2), 1303-6521. 
Buyukozturk, Ş., Kılıc Cakmak, E., Akgun, O.E., Karadeniz, Ş., and Demirel, F. (2011). Bilimsel araştırma yontemleri (Research Methods). Ankara: Pegem Akademi.

Chen, X. B. (2013). Tablets for informal language learning: Student usage and attitudes.

Language, Learning \& Technology, 17(1), 20-36.

Chu, H.C., Hwang, G.J., and Tsai, C.C. (2010). A knowledge engineering approach to developing mindtools for context-aware ubiquitous learning. Computers \& Education, 54(1), 289-297.

Ciampa, K. (2014). Learning in a mobile age: An investigation of student motivation. Journal

of Computer Assisted Learning, 30(1), 82-96.

Comes, H.P., and Kadereit, J.W. (1998). The effect of Quaternary climatic changes on plant distribution and evolution. Trends in Plant Science, 3(11), 432-438.

Cepni, S., Bayrakceken, S., Yılmaz, A., Yucel, C., Semerci, C., Kose, E., Sezgin, F., Demircioğlu, G., and Gundoğdu, K. (2008). Ölçme ve Değerlendirme (Measurement and Evaluation). Ankara: Pagem Akademi.

Davis, M.B., and Shaw, R.G. (2001). Range shifts and adaptive responses to Quaternary climate change. Science, 292(5517), 673-679.

Demirsoy, A. (2001). Yaşamın Temel Kuralları. Genel Biyoloji/ Genel Zooloji. Ankara: Meteksan.

Dynesius M., and Jansson, R. (2000). Evolutionary consequences of changes in species' geographical distributions driven by Milankovitch climate oscillations. Proc. Natl. Acad.Sci., 97,9115-20.

Eryılmaz, S. (2013). A Mobile-Based Instruction Application: The Effect of Mobile- Concept Instruction on Academic Achievement, Retention and Attitudes of Students. Journal of Education and Practice, 4(17), 205-217.

Fortner, R.W. (2001). Climate change in school: where does it fit and how ready are we?. Canadian Journal of Environmental Education (CJEE), 6(1), 18-31.

Georgieva, E., Smrikarov, A. and Georgiev, T. (2005, June). A general classification of mobile learning systems. It was presented International Conference on Computer Systems and Technologies. Varna: Bulgaristan.

Gowda, M., Fox, J., and Magelky, R. (1997). Students' understanding of climate change: Insights for scientists and educators. Bulletin of the American Meteorological Society, 78 (10), October, 2232-2240.

Hewitt, G. (2000). The genetic legacy of the Quaternary ice ages. Nature, 405, 907-913. doi: 10.1038/35016000. Abstract Revieved from http://www.nature.com/nature/journal/v405/n6789/full/405907a0.html

Hwang, G.J., and Chang, H.F. (2011). A formative assessment-based mobile learning approach to improving the learning attitudes and achievements of students. Computers \& Education, 56(4), 1023-1031.

Işık, A.H., Ozkaraca, O., and Guler, İ. (2011). Mobil Oğrenme ve Podcast. Akademik Bilişim'11-XIII. Akademik Bilişim Konferansı Bildirileri (XIII. Academic Computing Conference Proceedings) 2-4 February 2011 İnönü Üniversitesi, Malatya.

Jansson, R., and Dynesius, M. (2002). The fate of clades in a world of recurrent climatic change: Milankovitch oscillations and evolution. Annual Review of Ecology and Systematics, 741-777.

Jaradat, R. M. (2014). Students' attitudes and perceptions towards using m-learning for French language learning: A case study on Princess Nora University. International Journal of Learning Management Systems, 2(1), 33-44.

Karasar, N. (2008). Bilimsel Araştırma Yontemi (Scientific Research Method). Ankara: Nobel.

Kutluk, F. A. ve Gulmez, M. (2014). A research about mobile learning perspectives of university students who have accounting lessons. Procedia-Social and Behavioral Sciences, 116, 291-297.

Lombardi, D., and Sinatra, G.M. (2012). College students' perceptions about the plausibility of human induced climate change. Research in Science Education, 42(2), 201-217.

Mc Caffrey, M.S., and Buhr, S.M. (2008). Clarifying Climate Confusion: Addressing Systemic Holes, Cognitive Gaps, and Misconceptions Through Climate Literacy. Physical Geography, 29(6), 512-528. Doi: 10.2747/0272-3646.29.6.512

Ministry of National Education (MNE). (2013). Guncellenen Ogretim Programlari (The Updated Curriculum). From <http://ttkb.meb.gov.tr/www/guncellenen-ogretimprogramlari/ icerik/151> (Retrieved on 20 March 2015).

Ministry of National Education (MNE). (2014). 2014-2015 Egitim Ogretim Yilinda Okutulacak Ilk ve Orta Ogretim Ders Kitaplari (To be Instructed in the Academic Year 2014-2015 Primary and Secondary Education Textbooks). From <http://www.meb.gov.tr/2014-2015-egitim-ogretim-yilinda-okutulacakilk-ve-ortaogretim-derskitaplari/duyuru/7013> (Retrieved on 20 March 2015).

National Geographic. Ice Age Cycles. http://channel.nationalgeographic.com/videos/ice-agecycles/ (Retrieved on 20 March 2015). 
Oran, M.K., and Karadeniz, Ş. (2007). Internet Tabanlı Uzaktan Eğitimde Mobil Oğrenmenin Rolu (Role of Mobile Learning in Internet-Based Distance Education). Akademik Bilişim'07-IX. Akademik Bilişim Konferansı Bildirileri(IX. Academic Computing Conference Proceedings) 31 January - 2 February 2007 Dumlupınar Üniversitesi, Kütahya

Robock, A. (1978). Internally and externally caused climate change. Journal of The Atmospheric Science, 35, 1111-1122.

Schwarzacher, W. (1993). Cyclostratigraphy and the Milankovitch Theory. Elseiver Science Publishers: Netherlands.

Seppala, P., and Alamaki, H. (2003). Mobile learning in teacher training. Journal of computer assisted learning, 19(3), 330-335.

Shepardson, D.P., Niyogi, D., Choi, S., and Charusombat, U. (2009). Seventh grade students' conceptions of global warming and climate change. Environmental Education Research,15(5), 549-570.

Spiegel, D.S., Raymond, S.N., Dressing, C.D., Scharf, C.A., and Mitchell, J.L. (2010). Generalized Milankovitch cycles and long-term climatic habitability. The Astrophysical Journal, 721(2), 1308.

Tavşanoğlu, C. (2014). Kuresel değişim ekolojisi ders notları (Global change ecology lecture notes). <http://yunus.hacettepe.edu.tr/ ctavsan/BYL327/KDE-1.pdf > (Retrieved on 20 March 2015).

Turkeş, M. (2013). İklim değişiklikleri: Kambriyenden pleyistosene, gec holosenden 21. Yuzyıla (Climate change: the Cambrian from the Pleistocene until the late Holocene from the 21st Century). Ege Coğrafya Dergisi/ Ege Geographical Journal, 22(1), 1-25.

Wang, M., Shen, R., Novak, D., and Pan, X. (2009). The impact of mobile learning on students' learning behaviours and performance: Report from a large blended classroom. British Journal of Educational Technology, 40(4), 673-695.

Waycott, J., and Kukulska-Hulme, A. (2003). Student's experiences with PDAs for reading course materials. Personal and Ubiquitious Computing, 7(1),30-43.

\section{APPENDIX}

Achievement Test

1) Which of the following is among the causes of climate change?

I-Changes in the earth's orbit around the sun

II-Increase of greenhouse gases in the atmosphere

III-Global warming

A)Only I B) Only III C) II and III D)I and III E) I,II and III

2) Milankovitch cycles is one of the causes of climate change, which of the following can be said considering this cycle and its results?

A) Climate change has caused the extinction of many living species such as the mammoth

B) The spread of many plant and animal species have been fixed.

C) Obliquity and eccentricity are single-handedly effective on world climate.

D) The earth's axial tilt has no effect on climate change.

E) The existence of greenhouse gases in the earth's atmosphere naturally is a factor which triggers climate change.

3) I-Solar explosions

II-Astronomical relations between the earth and the sun

III-Release of the $\mathrm{CO} 2$ gas by people

Which of the above are among the external factors in climate change?

A)I and II B) II and III C) III and I D) I,II and III E) Only I

4) Which one of the factors causing climate change can be taken measures against?

A)Continental movements

B)CO2 increase

C)Stabilizing the earth's axis tilt

D)Change in the shape of the earth's orbit around the sun

E)The distance between the sun and the earth

5) What is the importance of the emergence of ice ages for the living beings on earth?

A) It has caused the mass extinction of species.

B) It caused the endangerment of the living by the release of greenhouse gases into

the atmosphere.

C) It has caused the halt of the evolution of the living.

D) It has caused the emergence of dinosaurs. 
E) It has caused the opening of new habitats to the living by giving rise to the crash of asteroids to the earth.

6) Which is the Milankovitch cycle that states the angle between the earth's axis and the plane of the ecliptic can change?

A) Axial tilt B)Obliquity C)Eccentricity D)Solar cycles E) Center deviation

7) Considering the Milankovitch cycle as well, which of the following can be said to be one of the effective factors in the emergence of glacial periods?

A) The oblateness of the earth's orbit around the sun is effective.

B) Asteroid crash

C) Supernova explosions

D) Lack of oxygen is oceans

E) Mass extinction of species

8) Which of the following is incorrect about the ice age?

A) The last ice age ended approximately 10.000 years ago.

B) Milankovitch cycles are the cause of the ice age.

C) Since the ending of the last ice age, the sea level has risen approximately 130 meters.

D) Throughout the last ice age, a warm and rainy climate prevailed in the Sahara Desert.

E) Throughout the last ice age, almost the whole planet was covered with ice.

9) Which of the following is not related to Milankovitch cycles?

A. They were described by a Serbian astronomer in the 1920s.

B. These cycles are among the external factors which cause climate change.

C. These cycles examine astronomical relations.

D. They explain the long-term climate changes which occurred throughout the Quaternary period.

E. They explain daily weather forecast

10. I. Axial tilt II. Orbital eccentricity III. Orbital precession of the earth IV. Diversity

of insolation periods

Which of the above is or are related to Milankovitch cycles?

A. I-II-III B.II-IV C. II-III D. I-II-III-IV E. I-II

11. Which of the following is incorrect according to Milankovitch cycles?

A. The angle between the earth's axis and plane of the ecliptic changes in 41.000-year periods.

B. When the axial tilt increases, the summers in both hemispheres are warmer.

C. The earth's orbit around the sun gradually turns into circular-shaped from ellipse and from circularshaped to ellipse again in a 100.000 year time.

D. When the earth's orbit is circular, the average energy amount it receives from the sun is lower.

E. The wobble of the earth's orbit is an event which makes the earth further from the sun only.

12. Which of the following cannot be said about the Quaternary glacial age which can be explained with Milankovitch cycles?

A. In this period, particularly the latitude and altitude range of tree taxons changed.

B. Woody plants started to become extinct.

C. Ground sloth, giant armadillo became extinct in the ice age of this period.

D. The current genetic structure of many species has been shaped mostly by the ice age of this period.

E. The expansion area of the living was limited in this period.

13. In which period did the last ice age occur?

A. Pleistocene B. Miocene C. Holocene D. Oligocene E. Paleocene

İletișim/Correspondence

Assoc. Prof. Dr. Sibel GÜRBÜZOĞLU YALMANCI

s.g.yalmanci@gmail.com 
